For citation: Semykina I. O. (2017). Managing Regional Economic Development through Local Content Requirements in Oil and Gas Industry. Ekonomika regiona [Economy of Region], 13(2), pp. 457-464

doi $10.17059 / 2017-2-11$

UCD: 332.142 .4

I. O. Semykina

Institute of Economics and Industrial Engineering of the Siberian Branch of RAS (Novosibirsk, Russian Federation; e-mail: semykina.irina@gmail.com)

\title{
MANAGING REGIONAL ECONOMIC DEVELOPMENT THROUGH LOCAL CONTENT REQUIREMENTS IN OIL AND GAS INDUSTRY ${ }^{1}$
}

\begin{abstract}
This paper explores the regional economic impact of mineral resource endowment and offers specific inputs to the debate on the local content requirement (LCR) policy, gaining urgency in modern economic and political environment. The paper considers the intricacies related to greenfield investment projects in Russian oil and gas industry. Focusing on the experience of the Krasnoyarsk region, the paper examines the way national companies operate in the newly developing oil and gas provinces of Russia. The analysis of key economic indices shows that the existing approach does not allow having significant benefits from resource endowment in the region. The main idea is that the establishment of completely new industry has to affect regional economic development, budget revenues dynamics and employment to influence the related industries and services in the region. The conducted analysis let to form possible scenarios and evaluate the dynamics of regional economic development depending on the scale of LCR policy. The developed approach based on statistical modeling allows assessing both direct and indirect effects of LCR policy. The obtained results allow to conclude that the implementation of LCR policy leads to the growth of real income per capita and the job creation in the region. The development of equipment and services suppliers for oil and gas industry by ripple effects can boost socio-economic development and diversify regional economy. The paper also dwells on some pitfalls and risks accompanying LCR policy and considers crucial points of introducing this kind of policy for local and federal government.
\end{abstract}

Keywords: regional economy, oil and gas industry, industrial policy, local content requirement policy, investments, greenfield project, inter-industry linkages, ripple effects, socio-economic development, Russia

\section{Introduction}

During the last years, Eastern Siberia regions have been providing the principal growth of the crude oil and gas production in Russia. Oil and gas industry of Eastern Siberia is been formed on the territory of three regions: Krasnoyarsk and Irkutsk regions and the southwest of Yakutia. But importantly, over the last few years, the bulk of the growth in crude oil production has actually come from the Krasnoyarsk region. In 2015, the production in these regions exceeded 37 million tones that is about $7 \%$ of annual production in Russia. The emergence of a new industry of the regional economy has a significant impact on the economic indicators growth: investment and GRP, personal income and regional budgets revenues. But the growth does not necessarily imply development.

As oil and gas fields' development and industry infrastructure construction in Eastern Siberia are often the sites of outsourced suppliers and human resources application this virtually eliminates the

\footnotetext{
${ }^{1}$ (c) Semykina I. O. Text. 2017.
}

possibility of deep inter-industry linkages of the projects in the region. Thus, the existing approach does not allow obtaining significant benefits from resource endowment in the region [1].

The long-term increase of hydrocarbons production while maintaining the dynamics of production in other sectors lead to negative structural changes in the regional economy-reducing the role of the manufacturing industries. It can be argued that structural change is unwanted, because it reduces the capacity of the economy to maintain sustainable growth after the oil boom [2]. The functioning of regional economies with a significant share of primary industries, particularly of oil and gas industry, has certain specificity. This is accounted for by the fact that the development of the oil and gas industry in the region is influenced by a variety of external factors such as the taxation system, price trends and the investment policy of mining companies which are outside of regional authorities competences. Moreover, the nature and scale of the oil and gas projects' influence on the regional socio-economic development dynamics varies in time depending on the stage of the project implementation. 
To eliminate the influence of these external factors, regional authorities have to diversify the economy away from its reliance on hydrocarbon extraction industry, bolstering the manufacturing industries. In general, regions have two sets of instruments to expand benefits from oil and gas extraction. One of them consists in tax revenue maximization. The development of oil and gas industry is expected to provide additional revenue to invest in infrastructure and other initiatives that can support the expansion of the industrial base [3]. Another way is local content maximization which implies the implementation of Local Content Requirement (LCR) policy. The World Trade Organization defines LCR as a 'requirement that the investor purchases a certain amount of local materials for incorporation in the investor's product'. In this sense, LCRs act as performance requirements that regulate the extent to which certain projects must use locally manufactured products. LCR policy is frequently bracketed with import-substitution industrialization (ISI) model. But unlike other protectionists' tools (high tariffs, appreciated currency, subsidized loans, the quantitative ban of imports, etc.), the percentage of local content establishes a global target allowing companies to manage it through different combinations of inputs. It can lead to import replacement but does not put it as a goal. LCR policy represents a kind of mechanism of transformation the mining industry costs in the incomes of other sectors of the regional economy, strengthening the linkages within the supply chain. The research aims to assess the LCR policy implementation impact on the regional economic growth dynamics, to verify whether it could cause qualitative changes in the key social indicators of regional development.

\section{Theoretical Framework}

The local economic development arguments of natural resource-rich countries were particularly originated in the resource curse hypothesis [4]. The theories of the paradox of plenty [5] and the resource curse $[6 ; 7]$ are of the opinion that countries with total dependence on natural resources such as oil and gas become the less developed and perform significantly worse than the countries that do not have this natural abundance. R. Auty [8], M. Ross, J. D. Sachs and A. M. Warner [9] are the examples of studies showing that the increase in mineral resource revenues may impede the economic development of a country, lead to an increase of social inequality and political instability. However, the resource curse syndrome can be avoided through proper management of revenues from resource extraction [10].
One of the strategies intended to expand and maximize the generation of externalities of extractive industries to benefit the territory is the LCR policy [11]. In the academic literature, there are several definitions of LCRs, but most researchers are of the opinion that this is the requirement, which is usually expressed as a percentage of the costs, of the local labor force and raw materials used in the manufacturing process in order to create the value added to the local economy. The first study on the local content is considered to be the work of American economist Gene M. Grossman published in 1981 where he evaluated the impact of local content protection measures on the market structure and the intermediate goods production [12].

LCRs were applied by different countries at different times and in different contexts, but commonly the authorities pay attention to such a mechanism in the wake of overcoming the crisis in the economy. For example, after the financial crisis of 2008, both developed and developing countries have turned to LCRs: over 100 new LCRs have been imposed [13]. As for developed countries, the basic motivation for the implementation of such a policy appears to be the possibility of job creation, among the fundamental objectives for developing countries are the infant industries protection and the ability to provide local companies with large foreign or domestic firms orders carrying out large-scale investments. Both developed and developing countries have been using the LCR policy in such sectors as the electric power, automotive, chemical, renewable energy, mining, oil and gas industries. In the oil and gas industry, LCR policy was for the first time introduced in Norway early in the 1970s while developing oil and gas fields in the North Sea and aimed technology transfer, the creation of new industries around the oil and gas projects, providing local people with jobs.

The estimates of the LCR policy usage influence on the economy are highly contradictory. While the number of scientists distinguish the effectiveness of this kind of policy in promoting infant industries, gaining competencies and the growth of production $[14 ; 15]$, others notice the risks of fostering imbalances in the market, rising costs for buyers, reducing foreign direct investments and incentives for technological development of the companies supported within the bounds of LCR policy [12; 13].

\section{Background}

In 2014, the GRP value of the Krasnoyarsk region was about 1.4 trillion rubles ( $2.4 \%$ of Russia's GDP), and ranked 10th among the regions. Since 


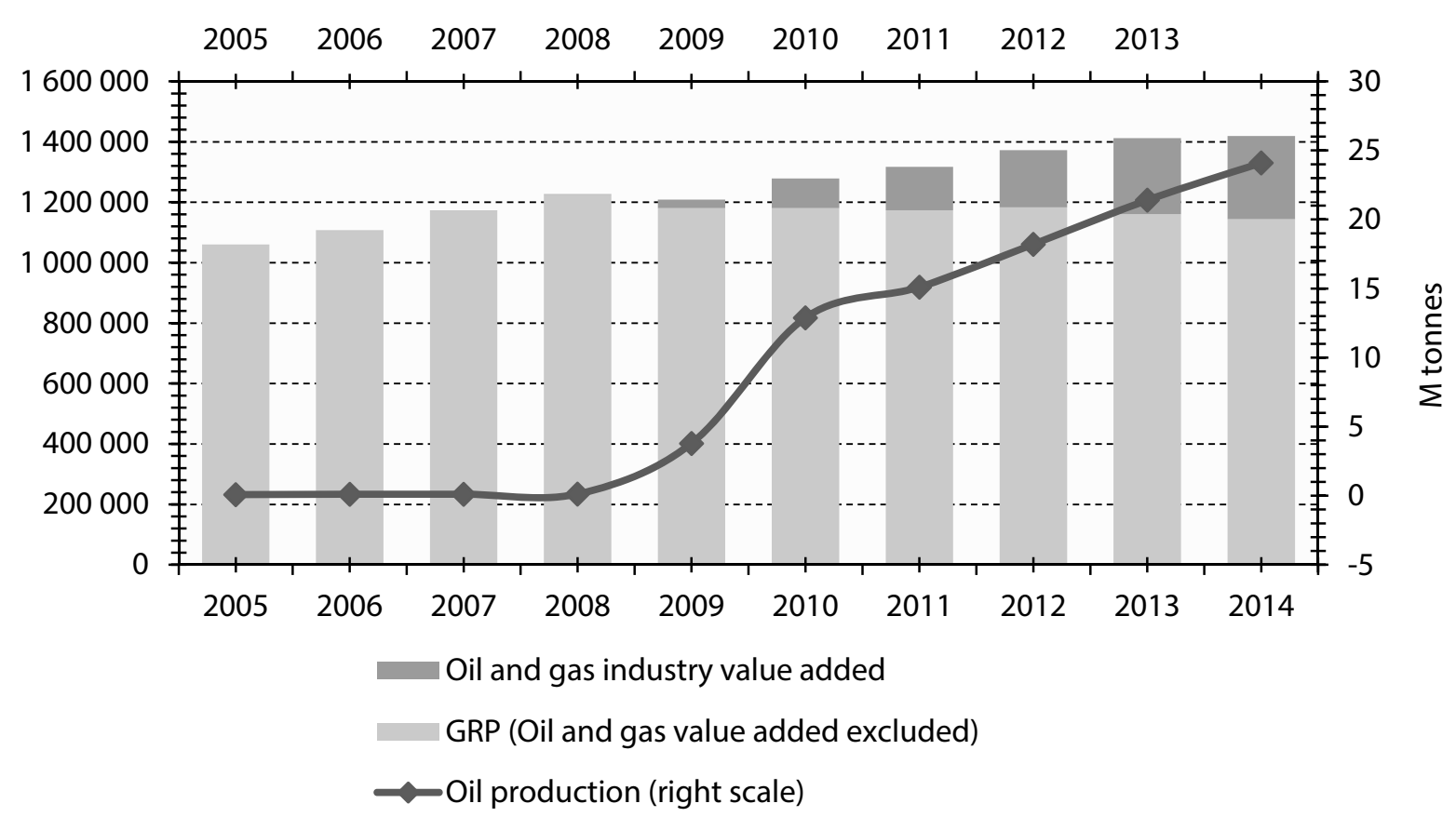

Fig. 1. Oil and gas industry in GRP of Krasnoyarsk region at constant prices of 2014

2009, the GRP growth rate in the Krasnoyarsk region has been constantly exceeded the all-Russian rate. The basis of industrial production of the region is represented by 3 industries: metallurgy (43.5\%), energy production (10.9\%) and mining (24\% in 2014).

From 2010 to 2014, the mining operations segment of Krasnoyarsk region has shown one of the highest average value added growth rate of $28 \%$ among Russian regions. The dynamics of oil production in the region is driven by Vankor oil field. In term of its contribution for national oil production, Vankor produced about $4.1 \%$ (22 million tons in 2015). Its share in the total production of Rosneft was about $11.5 \%$.

The implementation of Vankor project and its satellites provides a federal budget with tax revenues and allows fulfilling export obligations. The questions are: how this project has been contributing regional economy and how the dynamics of key regional economic indices has been changing since the start of Vankor field exploration in the mid-2000?

Today, in the Eastern Siberia, oil tax revenues do not fully depend on oil production. They are influenced by the financial results of the oil companies, which in turn depend on taxation regime and oil tax incentives. In 2010-2011, due to these incentives, Vankorneft along with Nornickel provided the largest amount of tax revenues in the region (about $7-10 \%$ of the budget revenues). In 2012, when Vankorneft joined the consolidated group of taxpayers, the volume of tax payments decreased significantly and ensured about $2 \%$ of revenues. The exit of Vankorneft from the consolidated group of taxpayers in 2015 allowed the regional budget to get additional 10 billion rubles providing about $6 \%$ of revenues.

The investments in oil and gas industry development in Krasnoyarsk region are about $10 \%$ of annual upstream investments of Russia. It would be reasonable to assume that industry plays a significant role in regional socio-economic development. In 2014, it ensured about $20 \%$ of regional investments and nearly $20 \%$ of GRP. If we look at the trend over the last 10 years in comparable prices, it really pops out that the growth rate of key economic indicator, after the Vankor field exploration start, has been significantly changed. Figure 1 provides the dynamics of the oil and gas industry share in GRP. During the last 6 years, the growth of GRP was provided just by oil and gas industry. At the same time, the growth of oil and gas industry investments was not accompanied by significant increase in investment and production in related sectors of the regional economy [16]. In 2011, 1000 rubles of investments in the fuel and energy resources extraction matched only 40 rubles of investment in machinery, equipment and vehicle production in the region. By 2015, first positive changes can be observed: the ratio reached 110 rubles per 1000 .

It has to be pointed out that there are inhibiting factors in the use of local materials and machinery which are occasioned by geological and technological challenges. The complexity of hydrocarbon fields in such areas does not allow using the experience and traditional approaches of min- 
ing. Moreover, the extraction and production of oil require a range of supply industry functions, none of which exist in the same region. There are also risks of not being able to find resources in line with company's standards, or enough competent staff for the required tasks. Back in 2006, which was the time of Vankor field development start, the engineering facilities and staff level in Krasnoyarsk region were completely unable to meet the needs of oil companies. The local procurement mostly consisted of so-called industrial upstream like building materials, metalware, and electric poles, sawmill products and etc. But the situation has been changing: in 2010, the School of Petroleum and Natural Gas Engineering in the Siberian State University was established; in 2011, OKB Zenith and Krasmash together with the Norwegian company Aker Solutions started the development of technological equipment for oil purification; in 2013, OKB Zenith launched the mass production of equipment for multi-stage fracturing.

Currently, there is no legislation governing local content requirements in Russia. It is the sphere of interaction between large businesses and regional authorities and addressed mainly as part of the corporate social responsibility agenda. However, starting from 2014, each annual report of national oil company Rosneft has been containing a chapter devoted to equipment and technology localization. Gazprom has also developed a set of measures which are intended to replace foreign procurement of goods, works and services. This reflects the willingness of oil companies, on the one hand, and growing opportunities of domestic engineering enterprises, on the other hand, to build a long term relationship.

The development of cooperation between basic industries enterprises (metallurgy, energy, oil and gas industry) and engineering companies of the region is stated among the main goals in the Project of the Strategy of Krasnoyarsk region till 2030. It is expected that regional service engineering enterprises will provide a significant part of basic industries procurement of the specialized machine-building production.

When it comes to local content, Norway is one of the leading nations in terms of policy. For Russia, the experience of such countries like Norway or Brazil is of great importance because of the high share of the state in the oil and gas companies. Norway had been fully exploiting the opportunities arising from the North Sea oil and gas resources to develop local capabilities. These capabilities developed as a result of collaboration and coordination, orchestrated and supported by the national and local governments [17]. The
Norwegian government has introduced legislation necessitating oil and gas companies contribute to economic development. Foreign operators entering Norwegian industry in the late 1970s were strongly encouraged to form R\&D partnerships and joint development programs with local companies and research institution. The operators' commitment and strategies for technology transfers were made a crucial factor in the licensing processes [18]. The development of supply chain strategy and the structure of the Norwegian oil and gas industry have been developed for about 30 years. When Statoil launched the Snohvit project, it had to develop a special strategy. According to it, each principal contractor had to prepare a project plan, taking into account the potential use of local suppliers, and local small and medium-sized companies in the north of Norway, which were given the role of sub-contractors for the specific types of services and production.

Norwegian local content strategy has been held up as an example of good practice for other countries. Brazil, for example, represents the same concept but uses different operating model. Realizing that the network of equipment and services suppliers were not prepared to supply competitively to the Brazilian oil and gas industry, the government introduced a clause for domestic content in the licensing process and created a PROMINP program that intends to increase domestic supply of equipment and services. Local content based on a percentage of local inputs in Brazil serves as bid factor in licensing round. It differs depending on the project phase-minimum $37 \%$ for the exploration, $55 \%$ until 2021 and $59 \%$ thereafter for the development phase [19]. They also introduced the requirement for the certification of $\mathrm{LC}$ and audit of reports. These measures together with technological strategy proved successful allowing Petrobras become a leading operator in the offshore.

Studying the experience of countries like UK, Norway, Brazil, Malaysia, sub-Saharan Africa, which have implemented models defining how technology and competence have to transferred or developed, reflects that local content is a positive development $[17 ; 19 ; 20]$. In addition, supporting local economic development by engaging local enterprises in the projects supply chain may ensure a sustainable development of the project and the area. Such benefits are of great importance especially for the Eastern Siberian regions which had been endured the alarming depopulation and deindustrialization processes since the collapse of Soviet Union in 1991. Oil and gas production is capital intensive industry, but at the same time involves a quite limited number of em- 
ployees. Equipment and machinery producing industries as well as oil and gas related services and engineering, on the contrary, can be referred to the highly skilled and labor-intensive sectors [21]. Moreover, linkages between oil and gas industry and other local industries may impact regional economic growth through investments and creating value-added activities in equipment and materials.

\section{Methods}

In recent years, there has been a growing understanding that the diverse nature of regions may preclude 'one-size-fit-all' solutions or general 'best practices' for regions and the need for policy recommendations to be differentiated is increasingly recognized. The optimization of local content targets' setting requires a quantitative analysis of planned project expenditures and the assessment of domestic supplier capabilities to identify a baseline scenario for local content. In order to properly assess LCR policy influence and avoid imbalances between project development and procurement functions, it is necessary to study the effects of projects in oil and gas industry on the regional economy and of local variables on the projects.

Studies aimed to measure the impact of LCR policy for the host economy usually employ an Input-Output (I-O) modeling framework, use Social Accounting Matrix (SAM) models [22] or the Competitive General Equilibrium (CGE) models [23]. But given the lack of regional I-O tables in Russia, this paper attempts to offer a specific approach based on a statistical simulation model. This approach is the development of ideas and methods which have been designed in the Institute of Economics and Industrial Engineering of the Siberian Branch of RAS for old oil-producing regions of Russia. As the oil and gas industry in Eastern Siberia is the newly developing one, identifying inter-industry linkages involves the use of simulation techniques. Within the simulation model by setting certain parameters (degree of localization costs in the region, the intensity of inter-industry linkages), we can execute the assessment of the impact of oil and gas projects on the socio-economic system of the region.

The proposed approach focuses not only on the direct effects of oil and gas industry on the regional economy (additional investment in the development of mining and processing of oil and gas resources, the growth of industrial output, tax revenue, employment, etc.), but also on the analysis of indirect impacts of related servicing sectors development.
The main proposition of the model is that the increase in localization costs of oil and gas companies within the territory leads to the increased intensity of inter-industry linkages in the region. Thus, increasing the share of local contractors in the oil and gas industry investment leads to the higher levels of investment and, consequently, the production and value added in the related industries. By related industries, we mean not only engineering, construction, drilling and service companies, but also such suppliers which depend heavily on oil and gas industry like transport, catering and other services. As a result, there are changes in employment and incomes, tax revenues in the regional budget. Furthermore, the model takes into account feedback showing the reducing costs by companies using local industrial products and services. Among the endogenous variables of the model, there are: volume of investment by industry, output by industry, industry value added, population size, the number of employees by industry; the number of unemployed and migrants, income per capita, budget revenues and expenditures. The regional economy structure is represented by the nine aggregated key sectors. For the forecast estimates on the volume of production in oil and gas industry, we have used forecast prices given by the International Energy Agency in World Energy Outlook in the 450 Scenario. The model has a forecast horizon of 21 years. The basic year is 2014, and all the cost parameters and indicators are given in comparable prices of 2014 .

The analysis is fulfilled depending on the nature and scope of the demands made by the oil and gas industry in the region. Within the conducted research, four possible scenarios have been simulated:

- Scenario I is a basic one and includes the determinants of the given Strategy of Social and Economic Development of Krasnoyarsk region till 2020, Project of Strategy of Social and Economic Development of Krasnoyarsk region till 2030, Industry Program 'Development of mining and processing of the fuel and energy resources in Krasnoyarsk region 2016-2018', Rosstat data, Krasnoyarskstat data, Ministry of Economic Development, Investment Policy and Foreign Relations of the Krasnoyarsk region data, Ministry of Finance of the Krasnoyarsk region data, World Energy Outlook 2015, Rosneft annual reports;

- Scenario II assumes that a certain part of construction works will be done by local firms. This type of activity includes exploratory drilling, construction of buildings, roads, installation of engineering equipment and other works. Estimates are made based on the assumption that the share 
Table 1

Forecast indicators summary by scenario at constant prices of 2014

\begin{tabular}{|l|c|c|c|c|}
\hline \multirow{2}{*}{ Indices } & \multicolumn{3}{c|}{ Scenario } \\
\cline { 2 - 5 } & I & II & III & IV \\
\hline Population, ths people & 2973.1 & 3030.3 & 3061.0 & 3068.1 \\
\hline CAGR of GRP, \% & 2.4 & 3.5 & 3.9 & 4.0 \\
\hline GRP per capita in 2035, ths rub & 789.9 & 955.1 & 1041.8 & 1059.8 \\
\hline Industrial output per capita in 2035, ths rub & 659.2 & 668.2 & 694.4 & 694.0 \\
\hline CAGR of investments, \% & 2.9 & 3.1 & 3.6 & 3.6 \\
\hline Investment per capita in 2035, ths rub & 211.0 & 215.6 & 237.5 & 236.1 \\
\hline CAGR of real income, \% & 1.8 & 2.4 & 2.8 & 2.9 \\
\hline Average monthly income per capita in 2035, ths rub & 35.1 & 39.9 & 43.5 & 44.2 \\
\hline Tax revenues per capita in 2035, ths rub & 127.4 & 130.1 & 161.9 & 160.3 \\
\hline Number of employees per 1,000 people in 2035 & 489.6 & 498.7 & 503.2 & 510.8 \\
\hline
\end{tabular}

of local contractors will have grown from the current 20 to $50 \%$ of the total volume of construction work for the oil and gas sector by the end of the forecast period;

- Scenario III involves the deployment of oil and gas processing capacities in the region;

- Scenario IV supposes the share of local engineering products to increase from current $1 \%$ to $25 \%$ by the end of the period.

The model allows evaluating defined strategies, determining the possible futures and testing the system's response to the effects of different scenarios. Depending on the LCRs, we may assess the benefits from the investments in the local content in order to maximize them.

\section{Appraisal}

The analysis of the obtained results has shown that the increase of local content share may have a significant impact on the dynamics of fixed assets investment in construction, transportation and manufacturing sectors. Thus, the forecast average annual growth rate of investment for the Scenario I is about $2.9 \%$ and more than $3.6 \%$ for Scenario IV. Compared with the III Scenario (the accumulated amount of investments for the period 11.3 trillion rub.), there is a slight decline in investments for Scenario IV (11.2 trillion rub.) due to the effect of cost reducing arising from the use of local machinery and equipment, as well as services of local contractors in the construction industry.

LCRs affect the production and services rendered in the region. The most significant increase in the socio-economic indicators at the beginning of the forecast period will be achieved mainly by extension the share of such nonspecific services as ones referred to 'Construction', which are directly dependent on investment in oil production. This is essentially due to the high capacity of construction market within the region: industrial construction ensures the demand for building materi- als, steel products, metal constructions, petroleum products, cable products and others. However, the slowdown in the production of hydrocarbons will lead to the reduction of the potential multiplier effects in construction. In the second half of the forecast period with the deployment of major processing facilities and the increase in engineering products supply, regional economy will be affected mostly by industries producing high value added products.

Increased production and value added in the capital-intensive sectors of the regional economy like oil and gas industry through the multiplier effects eventually leads to an increase in GRP of the Krasnoyarsk region. So in the Scenario I, the GRP increased by 1.6 times over the period, and in the Scenario IV -2.3 times for the period. Forecast estimates showed that the average annual GRP growth at Scenario I would be $2.4 \%$, II would provide a level of $3.5 \%$, III $-3.9 \%$, IV $-4.0 \%$ per year. By the formation of production chain in oil and gas related industries, the LCRs enable to achieve more than $1.5 \%$ increase in average annual GRP growth rate (Table 1).

Implementation of LCR policy will affect the real incomes: the average annual rate of growth in the IV Scenario will be $2.9 \%$ versus $1.8 \%$ at baseline. This, in turn, gives the opportunity to reverse the population decrease trend, which had been observed over the last 10 years. This trend is highly connected with the growth of real income per capita and the job creation in the region.

Taking into account the population size forecast and the required in the Scenario IV total number of employees, we can predict the necessary influx of people. In order to implement the planned projects, it is necessary to carry out a considered migration policy, aimed to attract a highly skilled workforce. It is also required training of local qualified engineering staff to serve high-tech enterprises in related sectors. 
The comparative analysis of the four scenarios has confirmed that the increase of local demand of the oil and gas industry companies allows achieving qualitative changes in key indicators of economic development. The development of a regional oil and gas engineering increases the efficiency of the industry by reducing capital costs. However, multiplicative effects of the development of oil and gas industry could not be a sound basis for economic growth in the long term. Oil and gas projects may influence the related industries and service especially at the initial stage of development, when major investments are carried out and the growing volume of work is performed in the exploration and development drilling, fields' development and infrastructure construction. In the stage of declining production multipliers effects will gradually decrease. In this regard, the sustainable development trends of the regional economy may be achieved through the establishment of the processing sector and engineering-oriented industries, or diversifying the economy, and researching other points of growth.

\section{Conclusion}

LCRs are able to involve local producers and labor in the implementation of oil and gas projects, to create multiple (indirect) effects through the regional inter-industry linkages. The development of equipment and services suppliers for oil and gas industry by ripple effects is able to boost economic development and diversify regional economy. Thus, the results of the calculations support the proposition that the LCR policy may be a kind of tool generating the induced economy. Moreover, the study shows a strong potential capacity of the regional economy to maintain sustainable growth exploiting and properly balancing the levers of LCR policy. Summarizing pre-conditions for successful policy implementation, it can be argued that LCRs must be introduced in a stable and sizable market which has the potential for growth. The larger the market, the more chance that welfare gains can be reached. In addition, a large and stable market encourages transfers of knowledge and technology. Second, to add value to the host economy, the percentage of local content required should not be too high and should be phased in gradually. The LCRs will be more effective when there is already a certain level of local capabilities. Using the appropriate economic and mathematical tools, it is possible to form special guidelines for either local or national governments in order to avoid situations when procurement expenditures may prop up inefficient industries instead of driving economic development.

\section{Acknowledgements}

This study has been supported by the Russian Foundation for Basic Research according to the research project No. 16-3600399.

\section{References}

1. Semykina, I. O. (2012). Nuzhen li vostochnoy Sibiri "neftegazovyy anklav"? [Does Eastern Siberia need "oil and gas enclave"]. Idei i idealy [Ideas and ideals], 3, 45-54.

2. Haddad, E. A. \& Giuberti, A. C. (2014). Economic impacts of natural resources on a regional economy: the case of the pre-salt oil discoveries in Espirito Santo, Brazil. Ekonomika regiona [Economy of region], 1, 111-124.

3. Esteves, A. M., Coyne, B. \& Moreno, A. (2013). Local Content Initiatives: Enhancing the Subnational Benefits of the Oil, Gas and Mining Sectors. New York: Natural Resource Governance Institute. Briefing. Retrieved from: http://www.resourcegovernance.org/publications/fact_sheets/local-contentinitiatives-enhancing-subnational-benefits-oil-gas-and-mining (date of access: 23.07.2016).

4. Ado, R. (2013). Local content policy and the WTO rules of trade related investment measures (TRIMS): the pros and cons. International Journal of Business and Management Studies. CD-ROM 2(1), 137-146.

5. Karl, T. L. (1997). The Paradox of Plenty: Oil Booms and Petro-states. Berkeley, CA: University of California Press, 380.

6. Auty, R. M. (1994). Industrial Policy Reform in Six Large Newly Industrializing Countries: The Resource Curse Thesis. World Development, 22(1), 11-26.

7. Ross, M. L. (1999). The Political Economy of the Resource Curse. World Politics, 51(2), 297-323.

8. Auty, R. M. (Ed.). (2001). Resource Abundance and Economic Development. New York: Oxford University Press, 360.

9. Sachs, J. D. \& Warner, A. M. (1995). Natural Resource Abundance and Economic Growth. National Bureau of Economic Research, Cambridge, MA. NBER Working Paper 5398.

10. Davis, G. A. (1995). Learning to Love the Dutch Disease. World Development, 23(10), 1765-1779.

11. Falco, De M., Gallo, M., Santillo, L. C., Troncone, E. PM. \& Viecelli, P. (2012). Planning large engineering project in high risk country areas: the evaluation of local content strategies in the oil \& gas industry through a robust planning technique. International Journal of Systems Applications, Engineering \& Development, 6(2), 213-221.

12. Grossman, G. M. (1981, November). The Theory of Domestic Content Protection and Content Preference. Quarterly Journal of Economics, 583-603. 
13. Hufbauer, G. C., Schott, J. J., Cimino-Isaacs, C., Vieiro, M. \& Wada, E. (2013). Local Content Requirements: A Global Problem. Policy Analyses in International Economics. Peterson Institute Press, 212.

14. Amsden, A. (2001). The Rise of 'The Rest': Challenges to the West from Late-Industrializing Economies. Oxford University Press, 405. doi:10.1093/0195139690.001.0001

15. Wade, R. (2003). Governing the Market: Economic Theory and the Role of Government in East Asian Industrialization. Princeton University Press, 496.

16. Semykina, I. O. (2012). Est' li u vas plan? [Do you have a plan?]. Eko [Eco], 6, 123-137.

17. Hatakenaka, S., Westenes, P., Gjelsvik M. \& Lester, R. K. (2006). The regional dynamics of innovation: A comparative case study of oil and gas industry development in Stavanger and Aberdeen. Industrial Performance Center, Massachusetts Institute of Technology. Working Paper 06-003.

18. Nordas, H. K., Vatne, E. \& Heum, P. (2003). The upstream petroleum industry and local industrial development: a comparative study. SNF Report No. 08/03.

19. Olsen, W. H. (2013). Brazil's local content policy, strategy and ambitions. INTSOK.

20. Klueh, U. H., Gonzalo, P. \& Alonso, S. (2009). Policies to improve the local impact from hydrocarbon extraction: Observations on West Africa and possible lessons for Central Asia. Energy Policy, 37, 1128-1144. doi: 10.1016/j.enpol.2008.07.042

21. Noreng, O. (2004). The Norwegian Experience of Economic Diversification in Relation to Petroleum Industry. Retrieved from: http://www.ogel.org/article.asp?key=1519 (date of access: 15.08.2016).

22. Dismukes, D. E., Olatubi, W. O., Mesyanzhinov, D. V. \& Pulsipher, A. G. (2003). Modeling the Economic Impacts of Offshore Oil and Gas Activities in the Gulf of Mexico: Methods and Applications. Prepared by the Center for Energy Studies, Louisiana State University, Baton Rouge, LA. OCS Study MMS 2003-018. 88.

23. Flaig, D. \& Stone, S. F. (2016). Local Content Requirements Versus Tariff Equivalents: How We Measure Matters. The World Economy. doi: 10.1111/twec.12426

\section{Author}

Irina Olegovna Semykina - PhD in Economics, Research Associate, Institute of Economics and Industrial Engineering of the Siberian Branch of RAS (17, Ac. Lavrentyeva St., Novosibirsk, 630090, Russian Federation; e-mail: semykina.irina@ gmail.com). 